\title{
PENGUKURAN SENYAWA POLYBROMINATED DIPHENYL ETHERS (PBDEs) DI UDARA AMBIEN MENGGUNAKAN POLYURETHANE FOAM- DISK (PUF-DISK)
}

\section{MEASUREMENT OF POLYBROMINATED DIPHENYL ETHERS (PBDEs) COMPOUNDS IN AMBIENT AIR USING POLYURETHANE FOAM-DISK (PUF-DISK)}

\author{
Dewi Ratnaningsih, Retno Puji Lestari, Arum Prajanti ${ }^{1}$
}

(Diterima tanggal 14 Juni 2017; Disetujui tanggal 22 September 2017)

\begin{abstract}
ABSTRAK
Polybrominated diphenyl ether (PBDEs) merupakan unsur pembentuk material tahan api. PBDEs berpotensi menimbulkan efek negatif terhadap mahluk hidup akibat memiliki sifat persisten, toksisitas, dan bioakumulatif. Pengukuran PBDEs dilakukan dengan pengambilan sampel menggunakan Polyurethane foam-disk (PUF-disk) yang dipasang pada passive air sampler (PAS) yang dipaparkan selama 58 hari dan 56 hari yang ditempatkan di dua lokasi yang mewakili daerah perkotaan (Casablanca, Jakarta) dan daerah pedesaan (Citeko, Bogor). Analisis hasil ekstraksi PUF menggunakan gas chromatography-mass spectrometry (GCMS) untuk menentukan sembilan kongener PBDEs yang terdiri dari BDE-17, -28, -47, -66, -99, -100, -153, -154, dan -183. Hasil menunjukkan semua jenis kongener PBDEs terdeteksi di Jakarta, sedangkan di Bogor hanya terdeteksi tujuh jenis. Konsentrasi PBDEs terdeteksi pada kisaran nilai 0,13-4,12 pg/ $\mathrm{m}^{3}$ di Jakarta, sedangkan di Bogor berada pada kisaran 0.09-2,59 pg/ $\mathrm{m}^{3}$. Kadar tertinggi ditemukan untuk BDE-47 di kedua wilayah. PBDEs terendah ditemukan untuk BDE-153 di perkotaan sedangkan BDE-153 dan BDE-183 tidak terdeteksi di wilayah pedesaan. Total konsentrasi 9 PBDEs ( $\sum$ PBDEs) yang terdeteksi di udara ambien di kawasan Casablanca, Jakarta sebesar 9,77 pg/m $\mathrm{m}^{3}$ dan di Citeko Bogor sebesar 5,71 pg/ $\mathrm{m}^{3}$. Berdasarkan persentase komposisi profil masing-masing BDE, maka kelimpahan terbanyak yang terdeteksi di udara baik di perkotaan dan pedesaan adalah BDE-47, dengan besar kelimpahan di pedesaan sebesar $45 \%$ dan di perkotaan 42\%. BDE-99 dan BDE-100 juga mempunyai persentase komposisi yang tinggi di pedesaan karena di perkotaan lebih banyak variasi BDE yang terdeteksi dibandingkand enan di pedesaan. Komposisi BDE lainnya yang mempunyai persentase lebih besar di perkotaan dibandingkan dengan di pedesaan adalah BDE-17, BDE-28, BDE-66, BDE-154, BDE-153 dan BDE-183.
\end{abstract}

Kata kunci: Polybrominated diphenyl ether, material tahan api, passive sampler, PUF-disk.

\begin{abstract}
Polybrominated diphenyl ethers (PBDEs) are the essential element of flame retardants material. PBDEs potentially shared the negative effect on living things regarding their persistency, toxicity, and bioaccumulation. Measurement of PBDEs was conducted using passive air sampler by installed the PUF-disk for 58 and 56 days, respectively, located in urban area (Casablanca, Jakarta) and rural area (Citeko, Bogor). Analysis of PUF's extract by gas chromatography-mass spectrometry (GCMS) was performed to determine nine congeners of PBDES (BDE-17, $-28,-47,-66,-99,-100,-153,-154$, and -183). The monitoring result showed that all congeners were detected in Jakarta, while in Bogor only seven were identified. PBDEs level in Jakarta ranged from 0,13 - 4,12 pg/ $\mathrm{m}^{3}$, while in Bogor ranged from $0.09-2,59 \mathrm{pg} / \mathrm{m}^{3}$. The highest level of BDE-47 were found in both areas. The lowest level of $B D E-153$ were found in urban area, while BDE-153 and BDE-183 were undetected in rural area. The total level of 9 PBDEs ( $\triangle P B D E S$ ) observed in ambient air in Casablanca-Jakarta was 9,77 pg/m and in Citeko-Bogor was $5,71 \mathrm{pg} / \mathrm{m}^{3}$. Based on the profile composition of each BDE in percentage, the most abundant BDE detected in both urban and rural air is BDE-47, with a $45 \%$ rural abundance and $42 \%$ in urban areas. The composition of BDE99 and BDE-100 detected in rural areas are relatively high compared to ones in urban areas. This occurred since the composition of BDE in rural areas is less varied than the urban areas. Other BDE compositions that have a greater percentage in urban than in rural areas are BDE-17, BDE-28, BDE-66, BDE-154, BDE-153 and BDE-183.
\end{abstract}

Keywords: Polybrominated diphenyl ether, flame retardants, passive sampler, PUF-disk

1) P3KLL-KLHK, Kawasan PUSPIPTEK, Gedung 210 Serpong, Tangerang - Banten T/F 021-7560981, 15310, emc_acdep@yahoo.com. 


\section{PENDAHULUAN}

Senyawa organik pada umumnya dapat ditransportasikan secara global tanpa mengenal batas wilayah maupun negara. PBDEs merupakan kelompok senyawa yang sudah termasuk dalam POPs (Persistent Organic Pollutants). Beberapa senyawa organik persisten perlu mendapat perhatian karena pada umumnya senyawa ini bersifat hidropobik, bioakumulatif, dan persisten (1, 2).

\section{Polybrominated diphenyl ethers (PBDEs)} merupakan senyawa organobromine yang masuk dalam kelas brominated hidrocarbon dan juga sebagai kelompok senyawa brominated flame retardant (BFRs) $(3,4)$. PBDEs diproduksi secara komersil sebagai campuran yang dikenal sebagai penta-BDE, okta-BDE, dan deka-BDE, yang mengandung kongener 4-6, 7-8, atau 10 atom bromine (5), dimana jumlah bromine yang rendah umumnya lebih bersifat bioakumulatif (6). PBDEs yang umum digunakan sebanyak 209 kongener dan mempunyai sifat serupa dengan PCBs (6). Senyawa PBDEs memiliki sifat stabil, tidak mudah larut dalam air, kelarutan yang tinggi dalam lemak. Seiring dengan penggunaan PBDEs secara masif, senyawa ini menjadi kontaminan global $(2,3$, 4). Keberadaan PBDEs telah dikonfirmasi di berbagai matrik lingkungan $(1,4)$. Senyawa ini digunakan sebagai flame retardant yaitu zat aditif yang ditambahkan dalam material atau bahan agar memenuhi standar legitimasi sifat flammable (mudah terbakar) (7), dengan tujuan untuk membuat suatu material menjadi lebih tahan terhadap api. Namun senyawa ini tidak terikat secara kimiawi terhadap struktur plastik, sehingga dapat dengan mudah terlepas ke lingkungan (8). PBDEs telah digunakan secara luas yang ditambahkan dalam berbagai produk plastik, furnitur, peralatan listrik, peralatan elektronik, tekstil-karpet, dan berbagai perabotan rumah tangga $(4,6,9,10)$. Penggunaan PBDEs di berbagai produk untuk konsumen telah memberikan jaminan terhadap kemampuan senyawa untuk memperlambat pembentukan material mudah terbakar (11).

PBDEs juga termasuk dalam senyawa endocrine disrupter compound yaitu kelompok senyawa yang dapat mengganggu fungsi hormon endokrin pada ikan maupun biota air lainnya (3). PBDEs telah menjadi perhatian karena bahaya dan dampak negatif yang ditimbulkan dari sifat toksisitas, persisten dan bioakumulasi senyawa tersebut (12). Komposisi detil campuran PBDEs sangat krusial untuk mengetahui potensi toksikologi dan efeknya terhadap lingkungan akibat biomagnifikasi beberapa kongener selektif, sifat degradasi, dan kemampuan transportasi (5). Sebuah studi toksikologi di Shanghai memperlihatkan bahwa paparan PBDEs terhadap manusia terdiri dari jalur inhalasi, ingesti (oral), dan dermal. Hasil penelitian menunjukkan bahwa debu merupakan sumber utama penyebab paparan PBDEs terhadap manusia. . Namun demikian, penilaian risiko menunjukkan bahwa jumlah paparan PBDEs tidak memperlihatkan adanya risiko kanker bagi penduduk setempat (13). Dampak kesehatan senyawa flame retardants menunjukkan tidak adanya potensi toksisitas akut. Studi toksisitas kronis tentang senyawa PBDEs yang dilakukan Darnerud (2003), van der Ven (2006), Dye (2007), dan Turyk (2008) mengindikasikan adanya efek dalam sistem hormon tiroid (6), sementara hasil penelitian Lichteinsteiger (2003 dan 2004), 
serta Kitamura et al. (2005) memperlihatkan terjadinya gangguan endokrin (6). Adanya perubahan pada neurodevelopment dihasilkan melalui hasil riset Viberg (2003), Eriksson (2006), dan Mariussen and Fonnum (2003) (6). Deka PBDE oleh US EPA diklasifikasikan sebagai possible human carcinogen, karena dari penelitian menunjukkan adanya peningkatan terjadinya tumor hati dan tumor tiroid pada hewan pengerat (rodent) (grup 2B) $(3,6)$.

Manufaktur dan penggunaan campuran penta-BDE dan okta-BDE telah dihentikan di US dan EU tahun 2006, namun paparan terhadap manusia tetap berlangsung akibat lambatnya respon pengganti produk PBDEs, keberadaan di matriks lingkungan, makanan terkontaminasi yang dikonsumsi secara tak sengaja, dan debu (7). Mengingat bahaya dari PBDEs maka informasi keberadaan senyawa PBDEs di lingkungan masih diperlukan. Sifat persisten senyawa ini juga memungkinkan keberadaan PBDEs di lingkungan termasuk di udara ambien.

Pengambilan sampel PBDEs di udara ambien dapat dilakukan dengan menggunakan metode aktif dan pasif. Pada kegiatan ini dilakukan aplikasi penggunaan PAS dengan PUF untuk pengambilan sampel yang digunakan dalam pengukuran PBDEs di udara ambien. Metode ini dimaksudkan agar sampel dalam bentuk gas akan lebih berinteraksi dengan PUF. Laju sampling dipengaruhi oleh kondisi meteorologi seperti kecepatan angin. Oleh karena itu selain menggunakan laju sampling berdasarkan penelitian sebelumnya, juga direkomendasikan untuk menggunakan laju sampling spesifik masing-masing lokasi dengan menggunakan depuration compounds (DC) (14). diasumsikan tidak terlalu banyak jenis aktifitas manusia.

\section{METODOLOGI}

Pengambilan sampel udara untuk pengukuran PBDEs di udara ambien secara pasif dengan menggunakan PAS yang berisi PUF-disk (AMETEC) dengan ukuran diameter $14 \mathrm{~cm}$, ketebalan 1,35 cm, area permukan $367 \mathrm{~cm}^{2}$, volume $208 \mathrm{~cm}^{3}$, ketebalan efektif 0,566 $\mathrm{cm}$, berat 6,08 g dan densitas 0,0293 g/ $\mathrm{cm}^{3}$ yang dikembangkan oleh Korea Ocean Research and Development Institute (KORDI) (15), sama dengan yang peralatan yang digunakan untuk pengambilan sampel POPs dan PAHs (1). Sampler yang berupa PUF disiapkan di laboratorium $\mathrm{Oil}$ and POPs Research Group KORDI. Dekstruksi PUF-disk menggunakan soklet secara bertahap dengan pelarut kemurnian tinggi yang merupakan campuran aseton dan metanol, kemudian petroleum ether, dan hexane masing-masing selama 16 jam, setelah sebelumnya dicuci dan dikeringkan pada suhu $60^{\circ} \mathrm{C}$ semalaman. Selanjutnya PUF-disk dikeringkan pada suhu $50^{\circ} \mathrm{C}$ selama 4 jam dengan menggunakan $d r y$ vacuum oven dengan purge gas $\mathrm{N}_{2}$.

PUF-disk segera dimasukkan dalam kaleng dan ditutup rapat untuk mencegah masuknya udara kedalam kaleng selama proses transportasi ke lokasi sampling (SOP KORDI). Kaleng penyimpanan PUF-disk terbuat dari stainless steel yang telah dibersihkan dengan air distilasi, kemudian diultrasonik dan dibilas dengan dichloromethane (DCM).

PUF-disk yang telah disiapkan ditempatkan di tengah wadah berbentuk dua kubah stainless steel (Gambar 1). Di antara dua kubah tersebut terdapat celah sebesar 2,5 $\mathrm{cm}$ yang berfungsi agar udara dapat masuk melewati celah tersebut dan mengalir melalui permukaan PUF-disk. 

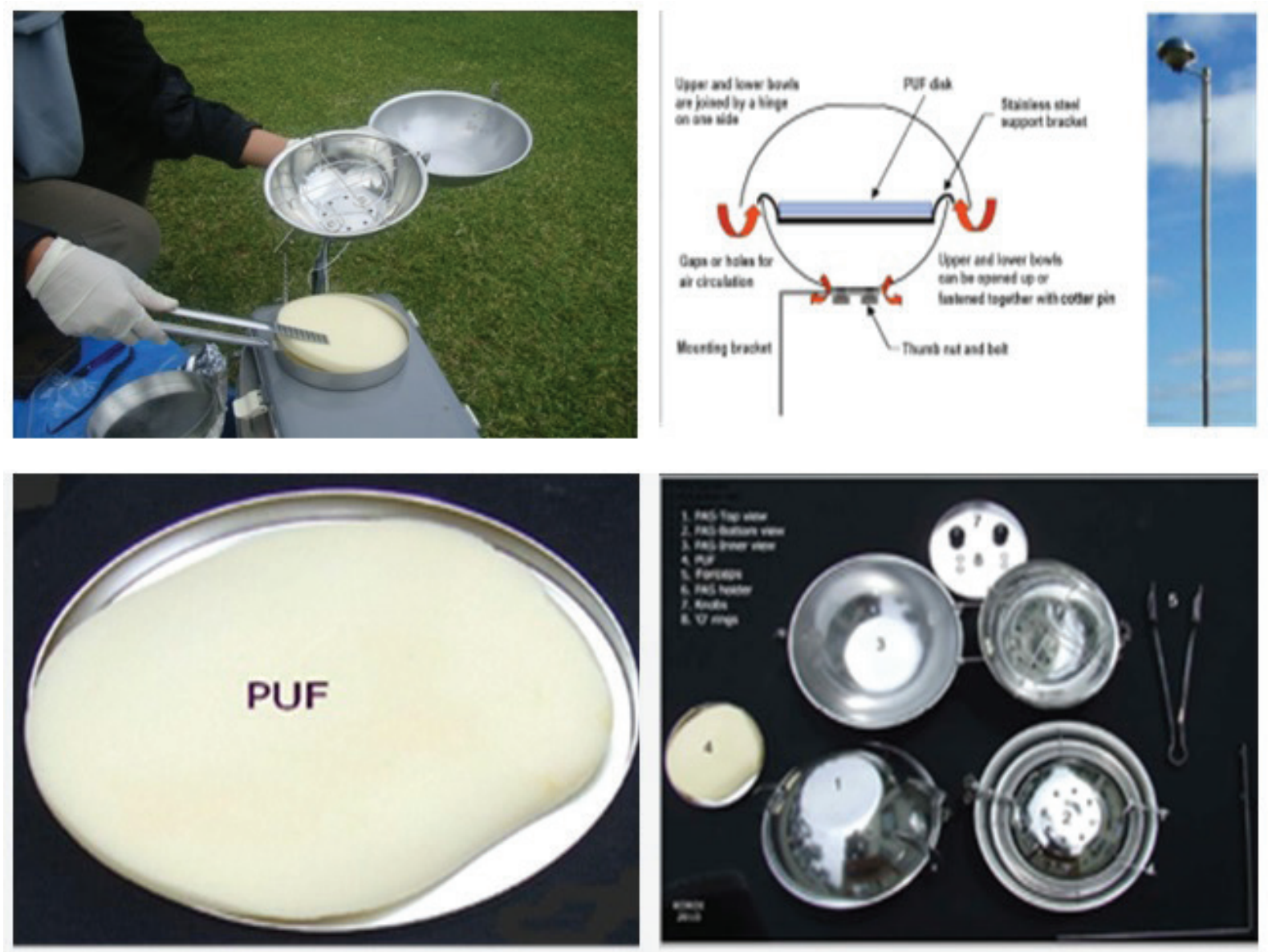

Gambar 1. PUF dalam PAS untuk pengambilan sampel PBDEs di udara ambien Sumber Data : SOP PAS Assembly and Development, KORDI Korea (15)

Pada penelitian ini titik sampling dilakukan di daerah perkotaan yaitu daerah yang dekat dengan transportasi dan aktifitas industri dan daerah pedesaan yaitu daerah yang diasumsikan tidak terlalu banyak jenis aktifitas manusia.

Penempatan PAS dilakukan di atap gedung yang berlokasi di kawasan Casablanca, Kuningan, Jakarta Selatan pada koordinat 6013'34.2”S, 106050'04.8'E dan di Citeko, Cisarua, Puncak, Kabupaten Bogor pada koordinat $6^{\circ} 42^{\prime} 38.51$ 'S, $106^{\circ} 57^{\prime} 0.62$ ' E". Titik sampling di lokasi Citeko berada pada ketinggian $1144 \mathrm{~m}$ dpl dengan lokasi sekitarnya sebagian besar untuk thortikultura dan bangunan vila. Lokasi Casablanca dikelilingi oleh aktifitas jalan raya dan gedung perkantoran. Paparan PUF di udara ambien dilakukan dalam kurun waktu 58 hari di Jakarta, sedangkan di Citeko, Bogor dilakukan paparan selama 56 hari.

PUFyangtelah dipaparkan diudaradimasukan ke dalam wadah stainles steel yang ditutup dengan isolasi teflon dan ditransportasikan ke Laboratorium Oil and POPs Research Group KORDI untuk dilakukan ekstraksi dan analisis. Ekstraksi PUF-disk dilakukan dengan menggunakan pelarut organik hexane dan diclorometane, sedangkan pemurnian dilakukan dengan kolom silica/alumina dan HPLC (size exclusion column packing with phenogel $100 \mathrm{~A})$. Analisis PBDEs yang terdiri dari BDE-17, -28, -47, -66, -99, -100, -153, -154, dan -183 dilakukan dengan GCMS yang dilengkapi kolom DB-1. 


\section{HASIL DAN PEMBAHASAN}

PBDEs sebagai senyawa yang ditambahkan dan dicampur dalam produk komersial yang digunakan dalam kehidupan sehari-hari bersifat campuran dan tidak terikat secara kimiawi. Hal ini akan mendorong mudahnya senyawa tersebut lepas ke lingkungan. Kondisi tersebut berpotensi terhadap terjadinya pencemaran PBDEs baik di air, udara, tanah maupun mahluk hidup termasuk manusia. Hasil pengukuran PBDEs di udara ambien yang diambil, di daerah perkotaan wilayah Casablanca, Jakarta maupun daerah pedesaan di Citeko, Bogor. menujukkan PBDEs yang terdeteksi di perkotaan lebih bervariasi dibandingkan dengan di pedesaan. Konsentrasi PBDEs yang terdeteksi juga bervariasi. dari sembilan jenis PBDE yang dianalisis semua jenis tersebut terdeteksi di perkotaan Jakarta, sedangkan di Bogor terdeteksi tujuh jenis PBDEs. Konsentrasi PBDEs terdeteksi di Jakarta pada kisaran nilai 0,13 - 4,12 pg/ $\mathrm{m}^{3}$, sedangkan di Bogor berada pada kisaran $0.09-2,59 \mathrm{pg} / \mathrm{m}^{3}$. Kadar tertinggi ditemukan untuk BDE-47 baik di perkotaan maupun di pedesaan. PBDE terendah ditemukan untuk BDE-153 di perkotaan sedangkan pada pedesaan , BDE-153 dan BDE-183 tidak terdeteksi. Total konsentrasi 9 PBDEs ( PBDEs) yang terdeteksi udara ambien di kawasan Casablanca, Jakarta sebesar 9,77 $\mathrm{pg} / \mathrm{m}^{3}$ dan di daerah pedesaan Citeko, Bogor sebesar $5,71 \mathrm{pg} / \mathrm{m}^{3}$. Tidak tersedia baku mutu untuk PBDEs di udara ambien di Indonesia.

Berdasarkan persentase komposisi profil masing-masing PBDE, maka dapat diketahui bahwa dari 9 jenis profil PBDEs kelimpahan terbanyak adalah BDE-47 yang mempunyai presentasi komposisi tertinggi baik untuk wilayah perkotaan maupun wilayah pedesaan. Di wilayah pedesaan Citeko, Bogor komposisi BDE-47 mempunyai persentase lebih tinggi dibandingkan dengan di perkotaan sebesar $45 \%$, sedangkan di perkotaan $42 \%$. Demikian juga untuk BDE-99 dan BDE100 mempunyai persentase komposisi yang lebih tinggi di pedesaan dibandingkan dengan di perkotaan. Komposisi BDE lainnya mempunyai persentase lebih besar di perkotaan dibandingkan dengan di pedesaan seperti BDE-17, BDE-28, BDE-66, BDE-154, BDE-153 dan BDE-183 (Gambar 1.).

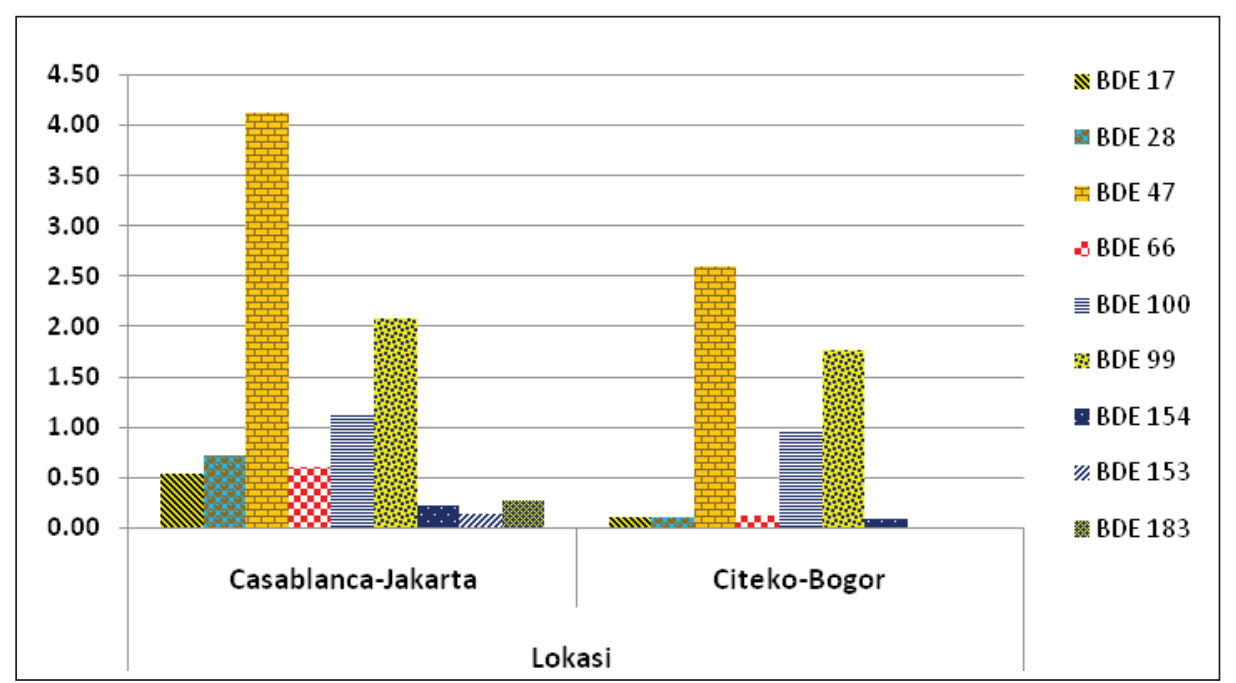

Grafik 1. Konsentrasi PBDEs yang terdeteksi di daerah urban Jakarta dan rural Citeko (pg/m³) 


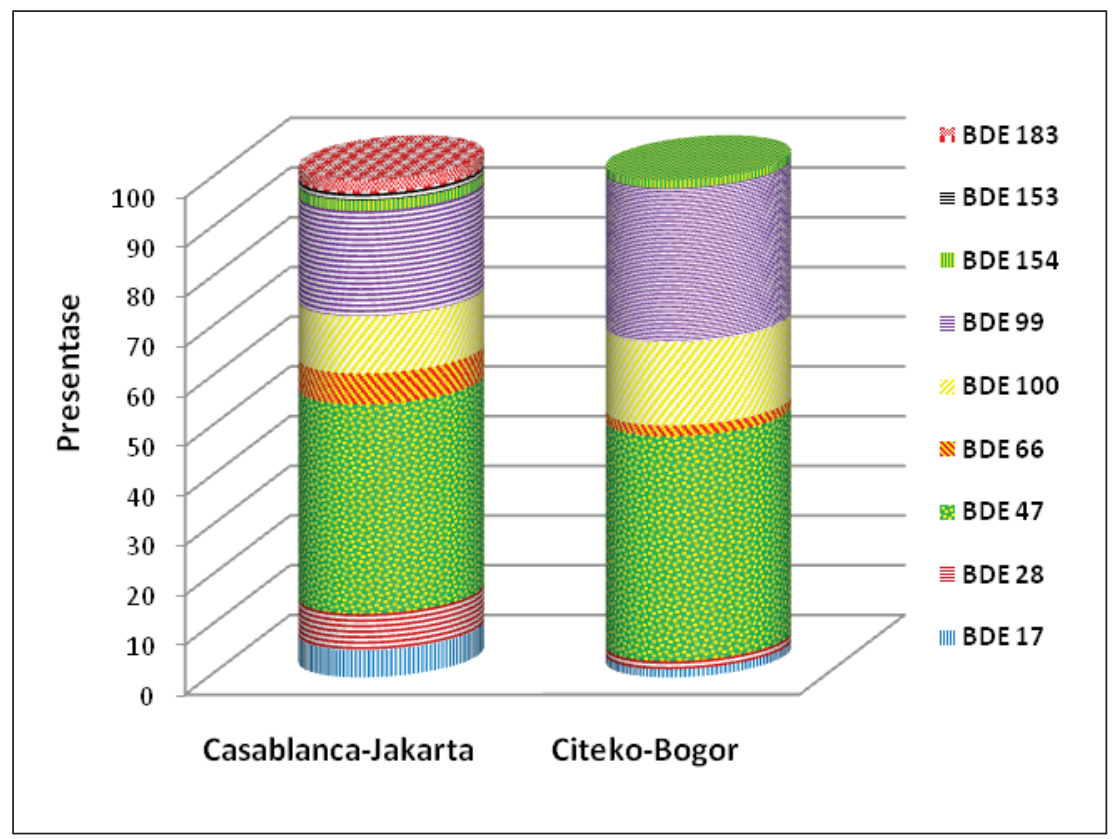

Grafik 2. Profil PBDEs di Udara Ambien

Senyawa 2,2',4,4'-tetrabromodiphenyl ether (BDE-47), komponen utama PBDEs yang terdeteksi dalam jaringan tubuh manusia dan sampel lingkungan, tidak mudah termetabolisasi dan bersifat bioakumulasi dalam jaringan lemak pada tubuh mahluk hidup $(16,17)$. BDE-47 paling banyak ditemukan karena digunakan sebagai komponen dalam campuran PBDEs komersial (18). Tidak tersedia data studi epidemiologi dan studi mengenai jalur absorpsi BDE-47 secara langsung terhadap manusia (19). Demikian pula dengan studi toksikologi kronis secara oral, inhalasi, dan reproduksi. Namun melalui studi jangka pendek dan sub-kronis terhadap hewan pengerat baik mencit maupun tikus, PBDEs diketahui berpotensi memberikan efek terhadap sistem hormon tiroid (19). Profil kongener PBDEs dalam media biologis umumnya berbeda dengan profil kongener campuran PBDEs komersial, dimana alasan terjadi perbedaan tersebut belum diketahui secara pasti (19).
Senyawa 2,2',4,4',5-Pentabromodiphenyl ether (BDE-99) merupakan komponen utama dalam campuran penta-BDE (5). Hites (2009) menyatakan bahwa BDE-99 merupakan kongener PBDEs yang umumnya ditemukan pada sampel lingkungan, sementara Daniels et al. (2010); Gómara et al., (2007); Sjödin et al.,(2008) menyatakan bahwa BDE-99 banyak ditemukan dalam sampel biologis seperti serum manusia, jaringan adipose, air susu ibu, dan darah tali pusar (7). Paparan BDE99 terhadap manusia merupakan penyebab terjadinya masalah kesehatan karena BDE-99 telah menunjukkan potensi bersifat neurotoxic dan dampak gangguan endokrin pada hewan uji (7).

Berdasarkan kongener PBDEs maka sembilan jenis BDEs yang dianalisis masuk dalam lima kelompok kongener yaitu tri-BDE, tetraBDE, penta-BDE, heksa-PBDEs dan heptaBDE. Profil kongener sering memberikan informasi yang berharga tentang sumber, dan jalur transportasi kontaminan di lingkungan 
(20). Tetra-BDE umumnya ditemukan berupa campuran dengan kongener tri-BDE dan heksa-BDE pada senyawa penta-BDE komersial (19). Campuran PBDEs komersial, deka-BDE umumnya terdiri dari kongener BDE-209 yang banyak diaplikasikan dalam material termoplastik, okta-BDE terdiri dari kongener-kongener BDE-153, BDE-183, BDE-196, BDE-197, BDE-203, BDE-207, dan BDE-209 yang juga diaplikasikan dalam material termoplastik, sementara campuran penta-PBDE terdiri dari kongener BDE-47, BDE-99, BDE-100, BDE-153, dan BDE-154 banyak digunakan untuk material polyurethane foam $(6,21,22)$.

Kongener dominan yang terdeteksi baik di perkotaan maupun di pedesaan adalah tetraBDE dan penta-BDE. Persentase kongener tertinggi untuk udara ambien di wilayah perkotaan adalah tetra-BDE sebesar 48\% dan diikuti oleh penta-BDE sebesar 32\%, sedangkan di wilayah pedesaan di Citeko, Bogor kongener tetra-BDE dan kongener penta-BDE mempunyai komposisi hampir sama, hanya selisih beberapa desimal yaitu sebesar $47,4 \%$ dan 47,8 \%. Campuran komersial penta-BDE sudah tidak digunakan lagi di Kanada. Hepta-BDE hanya mempunyai komposisi sebesar 2,7\% hexa-BDE juga mempunyai persentase komposisi yang kecil sebesar 3,5\% di perkotaan dan hanya 1,56\% di pedesaan. Parameter tri-BDE mempunyai selisih yang agak lebar antara udara ambien perkotaan dan pedesaan dibandingkan dengan kongener lainnya.

Keberadaan PBDEs dengan kadar yang lebih tinggi dan jenis yang lebih beragam di wilayah Jakarta dibandingkan dengan di wilayah pedesaan merupakan hal yang lazim karena di perkotaan penduduk lebih banyak sehingga penggunaan furnitur, alat-alat elektronik, maupun peralatan lainnya lebih banyak dibandingkan di pedesaan. PBDEs akan lebih banyak terlepas di perkotaan dibandingkan di pedesaan.

Kongener utama yang terdeteksi di seluruh sampel PUF berdasarkan hasil riset di Kuwait adalah BDE-47,-99, dan -100, yang merupakan kongener dominan dalam campuran penta-BDE komersil (23). Studi terdahulu menunjukkan adanya senyawa PBDEs (BDE-28, -47, -66, -100, -154, $-153,-183,-209)$ pada fase gas dan partikulat ditemukan di wilayah industri di Swedia (24).

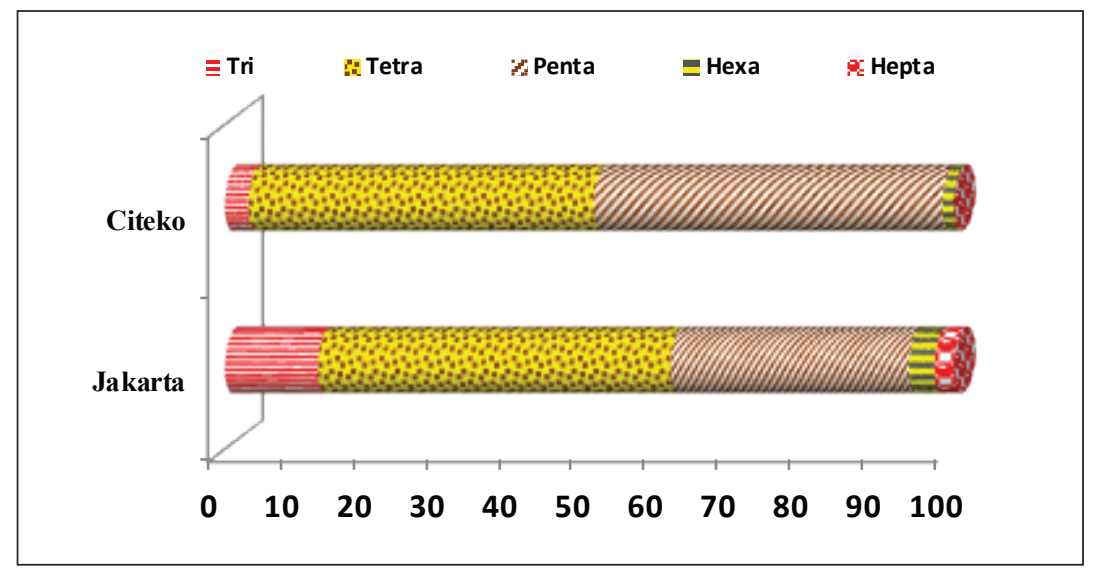

Grafik 3. Profil Kongener PBDEs di lokasi Casablanca, Jakarta dan Citeko, Bogor 
PBDE-47 dan PBDE-99 merupakan kongener dominan yang ditemukan dalam studi PBDEs di Kota Meksiko baik pada indoor maupun outdoor ambient, yang berkontribusi sebesar $47 \%$ dan $27 \%$ terhadap total komponen yang berhasil diidentifikasi yaitu PBDEs (28, 47, 49, 99, 100, 153, dan 154), dimana konsentrasi di indoor relatif lebih tinggi dibanding outdoor (25). Adapun penelitian konsentrasi PBDEs di atmosfer yang dilakukan di benua Antartika menunujukkan bahwa tri-BDE yaitu BDE-17 and BDE-28 merupakan komponen predominan, dan memiliki pola berbeda dibanding studi yang telah dilakukan oleh Shen et al., (2006), Su et al., (2007), dan Wang et al., (2005) yang mengidentifikasi keberadaan BDE-47 and BDE-99 sebagai kongener dominan di benua Arktik (26).

Sebuah riset di Asia mengenai berbagai senyawa organik di udara ambien dengan menggunakan PUF tahun 2004, berlokasi di Cina, Jepang, Korea Selatan, dan Singapura dilakukan untuk mengetahui konsentrasi polychlorinated biphenyls (PCBs), organoklorin (hexachlorobenzene (HCB), dichlorodiphenyltrichloroethanes (DDTs), chlordane), dan PBDEs. Konsentrasi rerata PBDEs dari seluruh wilayah pemantauan berkisar antara $<0,13-340 \mathrm{pg} / \mathrm{m}^{3}$, dan diketahui secara umum jauh relatif rendah dibanding senyawa organik persisten lainnya (27). Sementara di Cina, studi PBDEs dilakukan dengan cara pengambilan contoh uji menggunakan HVAS (active sampler) selama 24 jam di 15 lokasi (11 perkotaan, 1 sub perkotaan, dan 3 pedesaan). Sebanyak 12 skongener (BDE-17, -28, -47, -66, -85, -99, $-100,-138,-153,-154,-183$, and -209) berhasil diidentifikasi, dan diketahui bahwa BDE-209 mendominasi di wilayah perkotaan dan BDE47 di wilayah pedesaan (28).

\section{SIMPULAN}

Senyawa BDE-47 dan BDE-99 ditemukan sebagai senyawa dominan dari seluruh total 9 PBDEs yang dianalisis terdeteksi lebih tinggi di Jakarta dan lebih beragam dibandingkan dengan daerah pedesaan. BDE-153 dan BDE183 tidak ditemukan di daerah pedesaan.

\section{UCAPAN TERIMA KASIH}

Kepada Dr. Won Joon Shim, Dr. Sang Hee Hong dan semua personil Oil and POP Laboratory, Korean Ocean Research and Development Institute (KORDI melalui program AMETEC-UNU di Geoje, Korea Selatan diucapkan terimakasih atas kerjasamanya dalam mendukung kegiatan ini.,

\section{DAFTAR PUSTAKA}

1. Harner T, Pozo K, Gouin T, Macdonald A-M, Hung H, Cainey J, et al. Global pilot study for persistent organic pollutants (POPs) using PUF disk passive air samplers. Environmental Pollution. 2006;144(2):445-52.

2. Kalantzi OI, Martin FL, Thomas GO, Alcock RE, Tang HR, Drury SC, et al. Different Levels of Polybrominated Diphenyl Ethers (PBDEs) and Chlorinated Compounds in Breast Milk from Two U.K. Regions. Environmental Health Perspectives. 2004;112(10):1085-91.

3. ASTDR. Toxicological Profile for Polybrominated Diphenyl Ethers (PBDEs). 2004.

4. Akortia E, Okonkwo JO, Lupankwa M, Osae SD, Daso AP, Olukunle OI, et al. A review of sources, levels, and toxicity of polybrominated diphenyl ethers (PBDEs) and their transformation and transport in various environmental compartments. Environmental Reviews. 2016;24(Number 3). 
5. La Guardia MJ, Hale RC, Harvey E. Detailed polybrominated diphenyl ether (PBDE) congener composition of the widely used penta-, octa-, and deca-PBDE technical flame-retardant mixtures. Environmental science \& technology. 2006;40(20):6247-54.

6. Hong SH. Polybrominated diphenylethers (PBDEs): Introduction. Geoje: KIOST, 2012.

7. Erratico CA, Szeitz A, Bandiera S. Oxidative metabolism of BDE-99 by human liver microsomes: predominant role of CYP2B6. Toxicological Sciences. 2012:kfs215.

8. Charles MJ, Groskova D, Cahill TM. Near-Source Ambient Air Monitoring of Polybrominated Diphenyl Ethers California2005.

9. Li X, Li Y, Zhang Q, Wang P, Yang $\mathrm{H}$, Jiang $\mathrm{G}$, et al. Evaluation of atmospheric sources of $\mathrm{PCDD} / \mathrm{Fs}$, PCBs and PBDEs around a steel industrial complex in northeast China using passive air samplers. Chemosphere. 2011;84(7):957-63.

10. Webster TF, Stapleton HM, McClean MD. Exposure to polybrominated diphenyl ethers in the indoor environment. Fire Technology. 2015;51(1):85-95.

11. Hardy M, Biesemeier J, ManorO, Gentit W. Industry-sponsored research on the potential health and environmental effects of selected brominated flame retardants. Environment international. 2003;29(6):793-9.

12. Pozo K, Harner T, Wania F, Muir DC, Jones KC, Barrie LA. Toward a global network for persistent organic pollutants in air: results from the GAPS study. Environmental Science \& Technology. 2006;40(16):4867-73.
13. Li C, Zhao Z, Lei B, An J, Zhang X, Yu Y. Polybrominated diphenyl ethers in the air and comparison of the daily intake and uptake through inhalation by Shanghai residents with those through other matrices and routes. Environmental Science and Pollution Research. 2015;22(3):1750-9.

14. Pozo K, Harner T, Shoeib M, Urrutia $\mathrm{R}$, Barra R, Parra O, et al. Passivesampler derived air concentrations of persistent organic pollutants on a North- South transect in Chile. Environmental science \& technology. 2004;38(24):6529-37.

15. KORDI. Passive Air sampler assembly and Development, Standard Operation Procedure. Goeje, Korea: KORDI, 2011.

16. Erratico CA, Szeitz As, Bandiera SM. Biotransformation of 2, 2', 4, $4^{\prime}$-tetrabromodiphenyl ether (BDE$47)$ by human liver microsomes: identification of cytochrome P450 2B6 as the major enzyme involved. Chemical research in toxicology. 2013;26(5):721-31.

17. Hakk H, Huwe JK, Murphy K, Rutherford D. Metabolism of 2, 2', 4, 4'-tetrabromodiphenyl ether (BDE-47) in chickens. Journal of agricultural and food chemistry. 2010;58(15):8757-62.

18. D'silva K, Fernandes A, Rose M. Brominated organic micropollutantsigniting the flame retardant issue. Critical Reviews in Environmental Science and Technology. 2004;34(2):141-207.

19. EPA. Toxicological review of 2,2',4,4'-tetrabromodiphenyl ether (BDE-47) Washington, DC: U.S. Environmental Protection Agency; 2008. 
20. Barakat AO, Mostafa A, Wade TL, Sweet ST, El Sayed NB. Distribution and ecological risk of organochlorine pesticides and polychlorinated biphenyls in sediments from the Mediterranean coastal environment of Egypt. Chemosphere. 2013;93(3):54554.

21. Hardy ML. A comparison of the properties of the major commercial $\mathrm{PBDPO} / \mathrm{PBDE}$ product to those of major $\mathrm{PBB}$ and $\mathrm{PCB}$ products. Chemosphere. 2002;46(5):717-28.

22. Hardy M. The toxicology of the three commercial polybrominated diphenyl oxide (ether) flame retardants. Chemosphere. 2002;46(5):757-77.

23. Gevao B, Al-Omair A, Sweetman A, Al-Ali L, Al-Bahloul M, Helaleh $\mathrm{M}$, et al. Passive sampler-derived air concentrations for polybrominated diphenyl ethers and polycyclic aromatic hydrocarbons in Kuwait. Environmental toxicology and chemistry. 2006;25(6):1496-502.

24. Agrell C, ter Schure AFH, Sveder J, Bokenstrand A, Larsson P, Zegers BN. Polybrominated diphenyl ethers (PBDES) at a solid waste incineration plant I: Atmospheric concentrations. Atmospheric Environment. 2004;38(30):5139-48.
25. Bohlin $\mathrm{P}$, Jones $\mathrm{KC}$, Tovalin $\mathrm{H}$, Strandberg B. Observations on persistent organic pollutants in indoor and outdoor air using passive polyurethane foam samplers. Atmospheric Environment. 2008;42(31):7234-41.

26. Li Y, Geng D, Liu F, Wang T, Wang P, Zhang Q, et al. Study of PCBs and PBDEs in King George Island, Antarctica, using PUF passive air sampling. Atmospheric environment. 2012;51:140-5.

27. Jaward FM, Farrar NJ, Harner T, Sweetman AJ, Jones KC. Passive air sampling of PCBs, PBDEs, and organochlorine pesticides across Europe. Environmental Science \& Technology. 2004;38(1):34-41.

28. Yang M, Qi H, Jia H-L, Ren N-Q, Ding Y-S, Ma W-L, et al. Polybrominated Diphenyl Ethers in Air across China: Levels, Compositions, and Gas-Particle Partitioning. Environmental Science \& Technology. 2013;47(15):8978-84. 